\title{
GROUND VEGETATION-AN INDEX OF SITE QUALITY
}

\author{
By H. L. Holman
}

$\mathrm{F}$

ORESTERS of Finland, under the leadership of Mr. A. K. Cajander, have developed a very interesting theory of forest types which they have found to be of great practical value in the classification of the forests of Finland. In this connection, the reader is referred to the very able treatise on this subject by Cajander, entitled "The Theory of Forest Types". It would be impossible in this short paper to give a detailed explanation of theory, but some explanation is, of course, necessary.

Briefly, it may be said the theory is based upon the relationship that undoubtedly does exist between the ground flora and the forest itself. Many species of plants and trees with which we are familiar are associated in our minds with a habitat; thus we look for ferns in deep, moist hardwood forests, cacti on deserts, water-cress in running streams, willows near water, tamarack in swamps, and jackpine on low sandy ridges. These are some of the more obvious associations of plant and location. There are many others, but most of them are not so obvious for the reason that the very slight differences in location often make a habitat favourable for a species and such differences we cannot so readily perceive.

To a great extent, plant life is limited to habitats or favourable locations by the factor of competition with other species and it is a rare occurrence to find in nature a plant species occupying one location to the total exclusion of all other species. A certain element in the soil may favour a species in its competition for existence and thus hold it more or less to such soils, but as the locations differ in the amount of that element present, so will the plant differ in the frequency of its occurrence. This gives rise to types of associations of plant and tree species, and it has been found practicable to classify locations on the basis of types or associations of species rather than on the necessarily finer divisions based on the individual species.

All vegetation is affected in greater or less degree by the factors mentioned above, namely, competition with other species and adaption to environment. The lesser flora-mosses, plants and shrubs-have a short life span, and are many in species as compared with the tree species in the same region. It follows, then, that the types of the ground vegetation, due to the greater number of species, will react to smaller differences in location than will the trees, and also, due to their shorter life span, will reach their climax type or state of equilibrium much sooner. The trees also reflect these minor changes in location, but do so by growing faster or slower according as the situation is more or less favourable to them. They do not reflect it so readily by changes in the admixture of the species form. 
ing the forest type. Cajander states that the ground flora will attain its climax type about sixty years after it has been disturbed. We know that the trees cannot do so until at least one or two centuries have passed.

From the foregoing it is clear that there is a definite relation between the ground flora and the situation, between the forest and the situation and, therefore, between the ground flora and the forest, at least in theory. How does it work out in practice?

As stated before, the forests of Finland have been classified with this theory as a working basis. Moreover, Dr. Yrvo Ilvessalo has proved that tree species when growing with similar ground vegetative types have similar rates of growth and he has developed yield tables for spruce, pine and other species for different vegetative types previously determined and described.

It was the writer's privilege to be detailed to an investigation of the practicability of applying the Cajander Theory to our own northern forests, during the past summer. Having regard to the fact that our vegetative types, if they existed at all, had not been described and the fact that the Finnish types were only decided upon and described after many years' work by Cajander and his associates, it appeared best to carry on the investigation by comparing the vegetation found on a series of sample plots laid out with reference to the varying rates of growth of pure stands of timber. This method, of course, would not be the logical one to follow in an intensive study but the decision as to which vegetative types to use and which not to use is necessarily a matter involving considerably longer time than we had at our disposal and it was thought that results showing whether or not the theory is applicable to our forests mould be obtained most quickly in the manner described. Fortunately this turned out to be the case and the data collected by the season's work indicate very clearly that the ground flora and the forest bear a very close relation to one another -a relation which can, after further study, be put to practical use in determining site quality.

In general it may be said that our poorer sites check very closely with the Finnish types but that the two diverge as the quality of the site becomes better. As our work has so far been confined to Alberta it is probable that a description of our types, even if we were in a position to give them, would not be of interest nor any great value to foresters elsewhere and will not be attempted for that reason. In place of such a description, I have attempted a rough division of site quality corresponding to our usual Sites, I, II and III and based, very roughly, on the ground vegetation. It is as follows:

Site I. (A) Logs, due to natural thinnings, well rotted and covered with mosses and hepatics.

(B) Humus deep and well decomposed. 
(C) Lichens few or absent.

(D) Mosses in patches, rarely continuous, moist, luxuriant, old growth well rotted. Many species.

(E) Herbaceous vegetation luxuriant and consisting of many species. Characteristic species:-Viola sp., Vagnera sp., Heracleum, Mitela nuda, Actaea, Coptidium, Ferns, Oxalis and others.

(F) Shrubs, well developed willows and alders (in the west) Ribes, Corylus and others.

Site II. (A) Logs partially to fairly well rotted often covered with lichens and some mosses.

(B) Lichens, few on ground, many on logs.

(C) Humus not particularly deep and only partially decomposed.

(D) Mosses in partial to complete cover with luxuriant growth, mostly Hylocomiums on the ground with Ptilium cristacastrensis on the the better sites. Poorer sites will have great accumulation of unrotted old stems making the moss cover as a whole, very thick. Many species on logs.

(E) Herbaceous growth fairly luxuriant with a fair number of species-Pyrolas, Moneses, Fragaria, Mertensia, Petasites and many others. Grasses noticeable.

(F) Shrubs and dwarf shrubs very noticeable--Ledum, V. Vitis-Idaea, and other blueberries and cranberries (in the west), Shepherdia, Rosa, dwarf alders and willow, and many others.

Site III. (A) Logs unrotted or rotting very slowly, few or no lichens or moss on them.

(B) Grey lichens on the ground in great abundance, mostly Cladonia and Alectoria.

(C) Little or no humus.

(D) Mosses, dry species, in patches to partial cover, largely Hylocomiums. No great depth and dry.

(E) Herbaceous growth not luxuriant and poor in number of species-Antennaria microphylla, Hedysarum sulphurescens, Zygadenus elegans, and some others. Grasses scanty.

(F) Shrubs mostly depauperate and scanty. Arctostaphylos Uvaursi, Juniperis horizontalis, J. siberica and depauperate specimens of some species found in Site II.

As more work is done and the floristic types decided upon and described a much more satisfactory division of site values can be made. The idea of basing site quality upon the ground cover is new but, if it is shown to be satisfactory, it possesses several distinct advantages over the old methods, not the least of which is the fact that it will enable us to compare site values in widely separated districts. 